\title{
О выпуске
}

Этот номер нашего журнала посвящён памяти Ирины Альбертовны Халий - доктора социологических наук, руководителя Центра политологии и политической социологии Института социологии ФНИСЦ PAH, заместителя главного редактора Вестника ИС РАН, его бессменного выпускающего редактора и без преувеличения - его души.

Ирина Альбертовна страстно любила своё дело, в которое вкладывала смысл, выходящий за привычное понимание редакторского труда. Она была активистом, меняющим социальную реальность, и среди множества её идей всегда было пространство, в котором наши коллеги из регионов могли бы обсуждать местные и общие для страны и мира проблемы вместе и на равных со столичными и иностранными социологами. Таким пространством в итоге и стал наш Вестник.

Редколлегия Вестника приняла решение в память об И. Халий опубликовать в ближайших выпусках журнала несколько работ, посвящённых памяти Коллеги и Учителя. Открывает эту серию представленная в данном номере статья О. В. Аксеновой.

И. А. Халий как редактор считала, что из множества разных, а иногда и противоположных точек зрения авторов статей складывается достоверная картина российской жизни, её движущих сил и глубинных оснований. Это и определило тему данного номера - «Социальные детерминанты российского общества: вчера и сегодня», собравшую работы, в которых представлен анализ разных аспектов, разных уровней и разных составляющих социального устройства России и их изменений, в том числе исторических.

Выпуск открывает статья Л.А. Беляевой (Москва) «Структурация российского общества в XIX - начале XX вв. (по материалам отечественных исследований)», демонстрирующая одновременно процессы формирования структуры российского общества, её трансформаций и их изучение современниками. Статья представляет собой первую часть работы, посвящённой анализу социальной структурации за период с середины XIX в. по настоящее время. Хронология данной части охватывает временной отрезок до 1917 г. Процессы структурации рассматриваются через призму исследований, проводившихся в эпоху радикальных перемен в структуре российского общества. Главным событием, определившим направление общественных изменений, стала отмена крепостного права в Российской империи 1861 г., что вызвало сдвиги в структуре населения: ускоренное формирование рабочего класса, социальные преобразования на селе и развитие внутрироссийской миграции. В статье показано, что структурация населения 
на рубеже веков в территориальном аспекте существенно зависела от переселенческих движений и внутренней миграции. Эти процессы имели в России научное сопровождение, к их изучению подключились не только учёные, но и практики, активное участие в экспедиционных исследованиях приняла российская интеллигенция. Усилиями образованного сословия были получены ценные сведения о структуре общества, состоянии общественных отношений в России, миграционных процессах, социальных характеристиках основных структурных элементов общества - крестьян и рабочих.

В статье О. В. Аксеновой (Москва) «Субъект социального действия в современном развитии России: агент, актор, никто» рассматривается история создания концепции парадигмы социального действия, а также перспективы её применения для анализа современного развития России. В первой части представлены воспоминания о формировании концепции и о роли в этом процессе разработанных И. А. Халий принципов исследования, включающих изучение активизма, актуализированных ценностей и взгляд на социальные процессы с позиций локального сообщества. Показано, как был сделан вывод о ключевой роли действующего субъекта в традиционной для России модели управления и о возникновении идеи парадигмы социального действия как совокупности базовых свойств самого действия и его субъекта. Во второй части работы рассматриваются перспективы использования интерпретации социального действия как дихотомии свободного и алгоритмизированного действия для изучения процессов развития. Современный прогресс ориентирован на тотальную алгоритмизацию человеческой деятельности, поэтому результатом догоняющего российского развития может оказаться сведе́ние социального действия к алгоритму, а его субъекта - к функции, т. е. формирование человека, не способного мыслить и действовать самостоятельно. Поставлен вопрос, можно ли в таком случае данный вид трансформаций считать развитием или прогрессом?

Статья А. В. Немировской (Санкт-Петербург) и Н. Э. Соболевой (Москва) «Детерминанты субъективного благополучия в России: региональная перспектива» сфокусирована на восприятии собственного благополучия населением различных российских регионов. Целью исследования был анализ дифференциации в уровне субъективного благополучия населения различных российских регионов, который предполагает выявление факторов, объясняющих эти различия. Основным методом исследования стал регрессионный анализ данных социологических опросов, проведённых в 2012 г. по методике «Всемирного исследования ценностей» (WVS) в девяти регионах и городах федерального значения: Москве, Санкт-Петербурге, Ленинградской области, Тамбове, Республике Татарстан, Республике Чувашия, в Алтайском крае, Кабардино-Балкарской Республике, Республике Башкортостан. Анализ выявил взаимосвязь между уровнем личного дохода и субъективным благополучием. Связи 
последнего с богатством региона не обнаружено. В целом исследование подтверждает концепцию Р. Инглхарта о значимой роли материальной составляющей в субъективном благополучии, однако, кроме уровня дохода, субъективное благополучие также объясняют другие факторы (возраст, семейный статус, состояние здоровья, уровень образования, религиозность, наличие работы). Их влияние различается по регионам.

В статье Е. Б. Марина (Владивосток) «Образы российских политических лидеров в представлении молодёжи: семантическая реконструкция» показаны результаты эмпирического исследования представлений учащейся молодёжи Приморского края о российских политиках. Выявлены содержательные и структурные характеристики каждого образа, определена категориальная структура семантического пространства представлений о политических лидерах. К общим категориям, выделенным на основе ассоциаций, относятся прежде всего «лидерские», «нравственные и человеческие качества», «интеллектуальные», «отрицательные личностные качества» и «политическая символика» . Сравнительный анализ образов российских политиков показывает, что положительные личностные качества в представлении респондентов наиболее выражены у В. Путина и Р. Кадырова, оба являются носителями так называемых «лидерских качеств» и высоких морально-нравственных характеристик. Такие данные соответствуют запросу современного российского общества на компетентного, волевого и нравственно положительного лидера. Исследование позволило реконструировать структуру организации опыта субъективного восприятия политических лидеров и политического мышления молодых россиян.

Тема патриотизма современной молодёжи затронута в статье С. Г. Ивченкова и Е. В. Сайгановой (Саратов) «Ценностные ориентиры и их влияние на восприятие патриотизма у молодёжи». В ходе исследования, проведённого в Саратовской области методом массового опроса, были выявлены разнообразные модели патриотизма у молодых людей, а также трансформация этих моделей во времени. Показано, что многообразие ценностных доминант формирует семь моделей патриотических установок: абстрактный патриотизм, традиционный, локальный (включая семейный), либеральный, демократический, критический и глобалистский антипатриотизм. Темпорально все эти модели изменяются по разным, иногда противоположным векторам. Так, с возрастом значимость абстрактной и традиционной моделей патриотизма снижается, а локального и либерального - растёт (хотя доля семейного патриотизма, включённого в локальный, снижается). По мере взросления молодёжи значимость антипатриотической трактовки также снижается. На формирование патриотизма молодёжи больше всего влияет семья, затем (в порядке убывания значимости) общественные организации, структуры государственной власти, СМИ, система образования, религия. У всех социальных институтов российского общества обнаружен значительный нереализованный потенциал в деле формирования патриотизма молодёжи. 
Рубрика «Модернизация, стратегическое управление и социология» представлена двумя дополняющими друг друга статьями. В работе В. А. Корниловича (Москва) «Социальные детерминанты организации государственного стратегического управления» анализируется стратегическое управление как высшая функция государства, которая реализуется органами власти посредством системы государственного стратегического планирования и конкретного типа управленческой деятельности - разработки и реализации стратегий, национальных проектов и программ. Автором выявлена проблема в организации государственного стратегического управления, на которую указывает продолжающийся рост территориальных диспропорций в социально-экономическом, социокультурном развитии городов и регионов России, отстранённость населения от стратегий, федеральных и региональных проектов. $К$ числу факторов, ограничивающих способность органов власти к достижению планируемых результатов общественного развития, автор относит множество различных систем социального управления, сложившихся на региональном и муниципальном уровнях. Кроме того, в развитии локальных сообществ проявляется внутренняя детерминация, когда поведение выделяемой социальной целостности определяется не столько внешней причиной или управленческим воздействием, сколько характером внутренних связей, памятью о прошлых состояниях, правилами взаимодействия социальных субъектов и т. п. Решение проблемы организованности системы государственного стратегического управления и обеспечение управляемости процессов развития российского общества связано с раскрытием социальных факторов и явлений, определяющих допустимость новаций для локального сообщества.

И. А. Асеева (Курск) рассматривает проблему допустимости новаций с иной точки зрения. Её статья «Готовы ли россияне $\underline{\kappa}$ новой антропотехнореальности?» посвящена изучению социальной рефлексии влияния новых инфосоциальных технологий на повседневную жизнь человека и общества. В ней представлены результаты авторского социологического исследования «Современные социальные технологии как инструмент управления установками личности", проведённого в июненоябре 2019 г. среди жителей российского областного центра - г. Курска. В работе показано, как информационные и социальные технологии адаптируют современного человека к новой антропотехнореальности, формируя установку на изменение привычного образа жизни. В ходе исследования было выявлено значительное конвергирующее влияние информационных и социальных технологий на личность. Информационные технологии (интернет, в частности) являются самыми популярными источниками информации, в том числе и каналами, через которые осуществляются разнообразные манипулятивные воздействия на поведение личности, на готовность к конкретным и адресным действиям, на формирование нужного отношения группы или индивида к тому или иному явлению социальной действительности, навязывается определённый способ восприятия этого явления. 
Рубрика «Социология образования и воспитания: новые тенденции» также содержит две статьи, в которых представлены тенденции, возникшие в результате модернизации сферы социализации в её основных областях: в школьном образовании (профессиональная деятельность учителей) и семейном воспитании. В статье Н. В. Проказиной и В. Л. Ланцева (Орёл) «Роль общественнопрофессиональных объединений педагогов в условиях модернизации системы учительского роста» анализируется роль учительских ассоциаций в повышении профессиональных компетенций учителей. Целью исследования было установление взаимосвязи между активностью участия в деятельности подобных объединений и профессиональным становлением молодого учителя. Исследование проводилось на территории Орловской области. В качестве объекта исследования выступили члены региональной Ассоциации молодых учителей математики. В фокусе исследования находилось несколько аспектов учительской деятельности: профессиональные трудности молодых педагогов, система наставничества, ценностные ориентации личности учителя, профессиональное развитие. В статье показано, что активность участия в мероприятиях Ассоциации оказывает существенное влияние на ценностные ориентации личности в профессиональной сфере и позволяет молодым педагогам быстрее адаптироваться в профессиональном сообществе, способствует образованию устойчивых социальных связей с коллегами. В статье отмечается необходимость формирования системы наставничества в образовательных организациях, в том числе с использованием ресурсов общественнопрофессиональных объединений педагогов.

Цель исследования, представленного в статье И. Л. Сизовой (Санкт-Петербург) и М. М. Кореньковой (Нижний Новгород) «Новые потребительские практики современных городских семей в сфере ухода за детьми и их развития», заключается в выявлении характеристик потребления российскими матерями услуг по уходу за детьми и их развитию. Исследование проводилось в городском пространстве областного центра - Нижнего Новгорода. В статье рассматривается трансформация семейной функции воспитания, социализации и развития детей, а также формирование рынка платных семейных услуг, которые включают в себя услуги детских развивающих центров, платные дополнительные занятия в детском саду и школе, спортивные секции, танцы, рисование, иностранные языки; услуги по проведению детских праздников; услуги няней, психологов и тренеров по воспитанию детей. Авторы приходят к выводу, что современная городская семья стремится разделить ответственность за воспитание, уход и обучение своих детей с теми, кто выступает экспертами в этой области. Потребление услуг современными городскими семьями не отличается большим разнообразием, но зависит от стремления соответствовать современным требованиям воспитания и развития детей, высвобождения времени для собственных нужд и потребностей родителей, заботы о будущем ребёнка. 
Номер завершает рубрика «Социология международных отношений», представленная статьёй А. Л. Андреева (Москва) «Стратегическое партнёрство: $\kappa$ характеристике актуального политического феномена». Стратегическое партнёрство рассматривается как особая форма геополитического и геоэкономического взаимодействия, которое в обозримой перспективе может стать базовым элементом архитектоники современного глобального мира. Автор настаивает на том, что каждое конкретное стратегическое партнёрство формируется и поддерживается на основе уникального сочетания способствующих этому факторов, вследствие чего изучение такого рода процессов требует использования адекватных индивидуализирующих (идеографических) методов. В качестве примера предлагается анализ одного из наиболее показательных образцов такого рода - генезис и развитие отношений стратегического партнёрства между Россией и Индией. Анализируется зарождение «особых отношений» между двумя странами, их конвертирование в двустороннее политическое сотрудничество после провозглашения независимости Индии, а также динамика этого сотрудничества. На основании российско-индийского опыта формулируются некоторые общие условия формирования стратегических партнёрств. В ходе анализа перспектив дальнейшего развития стратегического партнёрства Российской федерации и Индии автор рассматривает геополитическое значение треугольника Москва - Дели - Пекин и заложенный в нём потенциал превращения Евразии в интегрированную инфраструктурными и природоохранными мегапроектами пространственную целостность.

Главный редактор журнала, Директор ФНИСЦ РАН Академик РАН М. К. Горшков 